\title{
ANALYSIS OF SOCIAL POLICY IMPLEMENTATION OF POVERTY ALLEVIATION BASED ON FAMILY (Study of Family Hope Program in South Timor Tengah Regency)
}

\author{
(1) Adrian H. A. Pentury, (2) Aloysius Liliweri, (3) David B. W. Pandie \\ Administrative Sciences Master Program, Postgraduate Program, University of Nusa Cendana, Kupang, East \\ Nusa Tenggara, Indonesia
}

\begin{abstract}
The purposes of this research are; (1) Finding out the social policy implementation of poverty alleviation based on the family on the Family Hope Program (PKH) in South Timor Tengah Regency. (2) Finding out the inhibitory factors of policy implementation of the Family Hope Program (PKH) in South Timor Tengah Regency. In this research, the author uses the interpretive paradigm with the action that is purposive in nature and the purpose is to understand the meaning of the research object. The type of research used in this research is the case study type with a qualitative descriptive method. The focuses on this research are; (1) Analysis of policy implementation on PKH in South Timor Tengah Regency, which is formulated in some research sub-focus namely; (a) Communication which is formulated again in some research sub-focus; (i) Information distribution method program (ii) The clarity on understanding the purpose of the program. (b) Resources which are also formulated into research sub-focus; (i) Level of Education; (ii) Supporting Facility; (iii) Budget. (c) Disposition of Tendencies for behavior and characteristic of policy implementing officer is also described into research subfocus; (i) Implementing Officer's Behavior; (i) Incentive. (d) Bureaucratic Structure is also formulated into research sub-focus; (i) SOP. (2) Inhibitory factors of policy implementation of PKH in South Timor Tengah Regency.

Based on the research results of the implementation of the Hope Family Program (PKH) in the South Timor Tengah Regency, it can be concluded that the program has run well. This can be seen from the role of implementing officers up to the beneficiary families. Policy implementations of PKH in South Timor Tengah Regency according to Edward III theory are: (1) Communication Dimension, Transmission or information distribution on the Hope Family Program given by the implementing officer has been understood well by the KPM. (2) Resources Dimension, Assistant has done a good mentorship process. However, facilities and infrastructure, regional topography in the implementation of PKH are not adequate in the mentorship process. (3) Disposition Dimension, Implementing an officer's behavior describes the commitment, the attitude of the beneficiary community of PKH who have done the obligation well. (4) Bureaucratic Structure Dimension, There is a standard operating procedure (SOP) for the implementation, so the coordination between social service, the government, and the assistant has been done perfectly.
\end{abstract}

Keywords: Implementation, Policy, Poverty Alleviation, Poverty

DOI: $10.7176 / \mathrm{DCS} / 10-4-09$

Publication date: April $30^{\text {th }} 2020$

\section{BACKGROUND}

Poverty is a situation where someone or a household experiences a difficulty to fulfill the basic needs, while their supporting environment give small to no chance to improve the welfare continuously or to get out of the vulnerability (Cahyat et al., 2007). BPS data in September 2017 states that the number of the poor population of poor people (people with the spending per capita per month is under the poverty line) in Indonesia has reached 26.58 million people or $10.12 \%$. The percentage of poor people in urban area is $7.26 \%$ while the percentage of poor people in the rural area is $12.47 \%$ (BPS, 2017).

It shows that the poverty issue still becomes a classic problem for Indonesia. Generally, poverty can be categorized into structural and cultural poverty based on its causes. Cultural poverty occurs due to the inability to exploit their potential, to prepare available resources, and to distance themselves from social activities and a culture of poverty through family lineages. Structural poverty as a result of external factors gives heavy pressure that makes a person or a community becomes powerless, for example, due to social systems and structures in society (Susanto, 2006).

As an effort to accelerate family-based poverty alleviation, since 2007 the Indonesian Government has implemented the Family Hope Program (PKH) by the Indonesian Ministry of Social Affairs which is based on the Decree of the Coordinating Minister for People's Welfare as the Chairperson of the poverty alleviation Coordinating Team, Number: 31/KEP/MENKO/-KESRA/IX/2007 concerning the Family Hope Program Controlling Team, September 21, 2007. Initially, PKH was only in 7 provinces, 48 districts/cities, and 337 sub- 
districts and served 387,947 RTSM, then it expanded until 2018. PKH has covered 34 provinces, 512 districts/cities, 7,214 districts, with a total recipient of 10,000,000 KPM.

Table 1.1. Development of KPM PKH Number

\begin{tabular}{|c|c|c|c|c|c|}
\hline No & Year & $\begin{array}{c}\text { Number of } \\
\text { Province }\end{array}$ & $\begin{array}{c}\text { Number of } \\
\text { District/City }\end{array}$ & $\begin{array}{c}\text { Number of Sub- } \\
\text { District }\end{array}$ & $\begin{array}{c}\text { Total } \\
\text { KPM PKH }\end{array}$ \\
\hline 1. & 2007 & 7 & 48 & 337 & 387,947 \\
\hline 2. & 2008 & 13 & 70 & 637 & 620,848 \\
\hline 3. & 2009 & 13 & 70 & 781 & 726,376 \\
\hline 4. & 2010 & 20 & 88 & 946 & 774,293 \\
\hline 5. & 2011 & 25 & 119 & 1,387 & $1,520,201$ \\
\hline 6. & 2012 & 33 & 169 & 2,001 & $1,454,655$ \\
\hline 7. & 2013 & 33 & 366 & 3,417 & $2,326,533$ \\
\hline 8. & 2014 & 34 & 418 & 4,870 & $2,871,827$ \\
\hline 9. & 2015 & 34 & 472 & 6,080 & $3,511,088$ \\
\hline 10. & 2016 & 34 & 504 & 6,402 & $5,981,528$ \\
\hline 11. & 2017 & 34 & 509 & 6,730 & $6,228,810$ \\
\hline 12 & 2018 & 34 & 512 & 7,214 & $10,000,000$ \\
\hline
\end{tabular}

Source: PPKH Center (2019)

The Hope Family Program (PKH) is a conditional social assistance program for poor and vulnerable families and/or individuals who are registered in the Integrated Data of Poor Handling Program (DT PPFM), processed by the Social Welfare Data and Information Center and determined as PKH beneficiary families (PKH Technical Directive, 2018).

To break the poverty chain, various policies and poverty alleviation programs have been implemented by establishing coordinating cross-sectoral and cross-stakeholder coordination at the central level to accelerate poverty alleviation through the National Team for the Acceleration of Poverty Alleviation (TNP2K). Established based on the Presidential Regulation of the Republic of Indonesia Number 15 of 2010 concerning the Acceleration of Poverty Alleviation. The government classifies poverty alleviation policies by the main poverty alleviation instruments which are divided into three policy clusters. First, the policy group based on social assistance and protection. This policy is in the form of programs that fulfill the main basic rights of poor individuals and households which include education, health services, food, sanitation, and clean water. Second, the policy group based on community empowerment. Third, the policy group based on the empowerment of micro and small businesses (TNP2K, 2010).

East Nusa Tenggara Province became one of the provinces with a population of poor people amounted to 1,142.17 thousand people or 21.35\% in March 2018 (BPS NTT, 2018). Data on poor households in South Timor Tengah Regency in 2012-2017 had an average of 68,864 poor households with a growth of $2.95 \%$. This illustrates that the number of poor households in South Timor Tengah Regency has fluctuated annually which can be seen on Table 1.2.

Table 1.2. Data on the Number of Poor Households in South Timor Tengah Regency

\begin{tabular}{|c|c|c|c|c|c|}
\hline No & Year & $\begin{array}{l}\text { Number of Poor } \\
\text { Households }\end{array}$ & Percentage & $\begin{array}{c}\text { Number of Poor } \\
\text { Population (inhabitant) }\end{array}$ & Percentage \\
\hline 1. & 2013 & 67,291 & - & 111,842 & - \\
\hline 2. & 2014 & 67,291 & 0 & 114,708 & 4.26 \\
\hline 3. & 2015 & 80,963 & 20.32 & 117,973 & 4.85 \\
\hline 4. & 2016 & 53,542 & -40.75 & 138,430 & 30.4 \\
\hline 5. & 2017 & 75,237 & 32.24 & 136,450 & -2.94 \\
\hline \multicolumn{2}{|c|}{ Average } & 68,864 & 2.95 & 123,881 & 9.14 \\
\hline
\end{tabular}

Source: TTS in Number (2018)

Since the beginning of the implementation of the Hope Family Program (PKH) in Indonesia, South Timor Tengah Regency is one of the 48 intervened regencies/cities. Through PKH, poor households in South Timor Tengah Regency can be encouraged to have access to and utilize basic social services in health, education, food and nutrition, care and assistance, including access to various other social protection programs which sustainably are part of complementary programs. $\mathrm{PKH}$ is directed to become a center of excellence for poverty alleviation 
that synergies various national social protection and empowerment programs (Guidelines for Implementation of PKH, 2017).

\section{Definition of Poverty}

\section{LITERATURE REVIEW}

According to Kurniawan Suparlan in Khomsan (2015), poverty can be defined as a low standard of living. There is a level of lack of wealth in a number or class of people compared to the standard of life that is generally applicable in the related society. This low standard of living has a direct effect on the level of health, moral life, and self-esteem of those who are categorized as poor.

Tjokrowinoto in Sulistiyani (2004: 27) states that: Poverty is not only a matter of welfare, poverty is also a matter of vulnerability, powerlessness, closed access to various employment opportunities, spending most of its income on consumption, high dependence rates, low access to markets, and poverty reflected in a culture of poverty inherited from one generation to the next one. Furthermore, Sulistiyani (2004: 27-28) states that: Poverty can be said as a condition that is far from the situation called prosperity. Prosperity is a condition where someone can meet his needs beyond the basic needs.

To measure poverty, BPS uses the ability to meet basic needs concepts (basic needs approach). Using this approach, poverty is seen as an inability to meet the basic needs of food from the economic side and it is not seen from food measured from the expenditure side. Thus, the poor population is the population that has an average monthly per capita expenditure under the poverty line.

Based on the aforementioned opinion defining poverty, it can be concluded that poverty is a situation of helplessness experienced by someone in fulfilling his basic necessities of life.

\section{Poverty Dimension}

According to Elis in Suharto (2010: 133) poverty is divided into several dimensions, namely: (1) The economic dimension, poverty is defined as a lack of resources that can be used to meet the basic necessities of life and improve the welfare of a group of people. The poverty standard in this dimension is measured by a standard known as the poverty line. (2) The political dimension, poverty can be seen from the level of access to power, (3) The social-psychological dimension, poverty which refers to the lack of networks and social structures that support in getting opportunities to increase productivity.

Suharto further states that poverty can be categorized into four categories namely; (1) Absolute poverty, which is a state of poverty caused by the inability of a person or group of people to meet their basic needs such as the need for food, clothing, education, health, transportation, and others. The determination of absolute poverty is measured through the poverty threshold or poverty line in the form of single or composite indicators, such as nutrition, calories, rice, income, expenditure, basic needs, or a combination of several indicators. To simplify measurement, it is usually converted in the form of money (income or expenditure) so that a person or group whose economic ability is below the poverty line can be categorized as absolutely poor. (2) Relative Poverty, poverty experienced by an individual or group compared to the general condition of society. For example, if the poverty line is Rp. 100,000 per capita every month, then someone who has an income of Rp. 125,000 per month is absolutely categorized as not poor, but if the average income of the local community is Rp. 200,000 per month, then that person is relatively included in the poor category. (3) Cultural Poverty, poverty which refers to attitudes, lifestyle, values, the social or cultural orientation of a person or society that is not in line with the spirit of progress of modern society. Laziness, no needs of achievement, fatalist, and past-oriented, no entrepreneurial spirit is characteristics of poverty in the cultural category. (4) Structural Poverty, poverty caused by structural injustice, whether political, social, or economic structures that do not allow a person or group of people to reach the sources of livelihood that are actually available for them. The existence of monopolistic and oligopolistic practices in the economic field, it will produce a chain of impoverishment that is difficult to solve. No matter how strong one's motivation and hard work, he will not be able to escape from the poverty chain in such a structural condition. The reason is because assets and access to resources have been controlled by a certain group of people.

\section{Poverty Alleviation}

According to Law Number 11 of 2009 concerning Social Welfare, Poverty Alleviation is a policy, program, and activity carried out for people, families, groups and/or communities who do not have a source of livelihood or those who cannot meet the decent needs as a human.

Poverty alleviation is aimed at; (a) increasing the capacity and developing the basic capabilities and business ability of the poor people; (b) strengthening the role of the poor in making public policy decisions that guarantee respect, protection, and fulfillment of basic rights; (c) realizing economic, political, and social condition as well as environment that enables poor people to get the greatest opportunity in fulfilling basic rights 
and improving living standards in a sustainable manner; (d) providing security for poor people and vulnerable groups.

Poverty alleviation is carried out in the form of counseling and social guidance, social services, providing access to employment and business opportunities, providing access to basic education services, providing access to housing and settlement services and providing training access, business capital, and marketing of business products.

\section{Poverty Alleviation Strategies}

Indonesian government formulated the following 4 (four) main strategies of poverty alleviation through the National Team for the Acceleration of poverty alleviation (TNP2K) to support comprehensive poverty alleviation and to realize the acceleration of poverty alleviation;

Strategy 1: Improving the Social Protection Program; The first principle is to improve and develop social protection systems for poor and vulnerable populations. The social protection system is intended to help individuals and communities deal with shocks in life, such as falling ill, death of family members, losing their jobs, being hit by disasters or natural disasters, and so on. An effective social protection system will anticipate that a person or community who experiences a shock does not fall into poverty.

Strategy 2: Increasing Access to Basic Services; The second principle in poverty alleviation is to improve access of poor communities to basic services. Access to education, health, clean water and sanitation services, as well as food and nutrition will help reduce the costs that must be incurred by poor people. On the other hand, increasing access to basic services encourages investment in human capital.

Strategy 3: Empowerment of Poor Groups; The third principle is that the effort to empower poor people becomes very important to increase the effectiveness and sustainability of poverty alleviation. In the effort to reduce poverty, it is very important not to treat the poor as mere objects of development. The effort to empower the poor population should be carried out so that they can make an effort to escape from poverty and not fall back into it.

Strategy 4: Inclusive Development; The Inclusive development as the fourth principle is defined as development that can involve and give benefits to the entire community at the same time. Participation is a keyword of the entire development implementation. Facts in various countries show that poverty can only be reduced in a dynamically growing economy. Conversely, stagnant economic growth can almost certainly lead to an increase in poverty. Growth must be able to create large numbers of productive employment. Furthermore, it is hoped that there will be a multiplier effect on the increase of income on the majority of the population, improvement of living standards, and reduction in poverty.

\section{The Understanding of Policy Implementation}

According to Nugroho (2017: 728), Implementation of policy in principle is a way for a policy to achieve its objectives. There are two steps namely direct implementation in the form of programs or the formulation of derivative policies or derivatives of these public policies, nothing more than to implement public policies.

Widodo (2001: 191) states that: Legalized public policy will not be useful if it is not implemented. This is because the implementation of public policies seeks to bring abstract public policies into reality. In other words, the implementation of public policy seeks to produce outcomes that can be enjoyed primarily by the target groups.

Lester and Stewart in Winarno (2016: 134) state that policy implementation is seen in a broad sense, constituting the stage of the policy process immediately after the enactment of the law. Implementation is widely seen as having the meaning of implementing a law whereby various actors, organizations, procedures, and techniques work together to carry out policies in an effort to achieve targeted policies or programs. Implementation, on the other hand, is a complex phenomenon that might be understood as a process, an output or as an impact (outcome).

\section{Public Policy}

In general, the term policy is interpreted as an actor (an official, a group, or a government agency) or a number of actors in a particular field of activity. To be able to understand more deeply, here are some opinions of experts about the concept of public policy. According to Robert Eyestone, public policy can be defined as "the relationship between government units with its environment". Whereas Thomas R. Dye says that "public policy is anything that the government chooses to carry out and not" (Budi Winarno, 2017: 19).

Furthermore, J. Anderson (Budi Winarto, 2017: 18) states that generally the term policy is used to refer to the behavior of an actor such as an official, a group, or a government agency or a number of actors in a particular 
field of activity. According to Anderson, the concept or understanding of public policy has several implications, namely: (1) Our point of attention in discussing public policy is oriented towards intention or goal and not arbitrary behavior. (2) The policy is the direction or pattern of action taken by government officials and it is not a separate decision. (3) The policy is what the government actually does in regulating trade, controlling inflation, or promoting public housing. It is not what the government desires. (4) Public policies may form positive or negative biases. Positively, the policy may include clear forms of government action to influence a particular problem. Negatively, the policy might include a decision by government officials. However, it is not intended to take action and do something about an issue that requires government involvement.

Conceptually, public policy can be seen from the Public Administration dictionary of Chandler and Plano (Nugroho, 2009), saying that public policy is the strategic utilization of available resources to solve public or government problems. Even Chandler and Plano assume that public policy is a form of continuous investment by the government for the sake of powerless people in society so that they can live and participate in the government.

\section{Public Policy Implementation Model by George C. Edward III}

Policy implementation in the era before the 1970s still has not received serious attention from public administrators and policymakers, although studies on public policy began to develop in the 1950s, as Edward III states through studies on the government of the United States of America. In the 1970s, problems arose in relation to the implementation and application of policies, as stated by Edwards III (1980: 9-10) as follows: "four critical factors or variables in implementing public policy: communication, resources, dispositions or attitudes and bureaucratic structure."

Those four factors or variables are symptomatic of why a policy that has been formulated is not achieved in accordance with the objectives in its implementation? The four dimensions of the cause of the nonimplementation of the policy or program can be explained as follows;

Communication is an important dimension for public administrators in implementing policies, especially for the achievement of program effectiveness through appropriate personal transmission, the intelligibility of instructed order by superiors in the implementation of the field and the consistency of implementing decisions or programs by all implementers and superiors in giving the instructions. There are 3 important aspects in this communication dimension that should be considered concerning the indicators such as; (1) Transmission, public administrators should have understood, clearly acknowledging the decision, and readiness to carry out orders that have been decided in every policy or program to be implemented, which they will most likely not free from obstacles and transmitting the order, this is related to: (a) There are contradictions in opinions by the field implementers on orders issued by officials who instruct or take policies (disagreement of implementers); (b) The distortion of information through the bureaucratic hierarchy of the order issuer (distortion may arise as information passes through multiple layers of the bureaucratic hierarchy); (c) Interpretation of orders received by implementers is hampered by selective perception and implementing non-compliance with predetermined policy requirements (implementers selective perception and disinclination to know about a policy's requirements). (2) Clarity, the implementation of the policy to be implemented by the implementers must be clear in terms of its purpose and objectives through implementing instructions as well as technical instructions that are carefully and comprehensively understood. There are 6 factors that make communication unclear in implementing policies as stated by Edwards III (1980: 26), namely: (a) Complexity of public policies; (b) The desire not to irritate segments of public; (c) Lack of consensus on the goals of a policy; (d) The problems in starting up a new policy; (e) Avoiding accountability for policies; (f) The nature of judicial decision making. (3) Consistency, the effectiveness of policy implementation will work if clear objectives can be carried out consistently by the implementers in the field based on the consistency of the policymakers in predicting the probabilities during the implementation. The inconsistency of the implementer in implementing policies from the top-level up to the implementers in the field is likely to cause distortion in the achievement of the program. (4) Implementation of the policy will be effective through the communication of instructions that are clearly and consistently instructed in its implementation. Unclear communication will lead to implementers' inconsistency in the field, as stated Edwards III (1980: 42), as follows: (a) Complexity of public policies; (b) The problems in starting up a new policy; (c) Multiple objectives of many policies.

Resources, policy implementation will not run effectively in its implementation if the carrying capacity of resources is weak or imperfect, as stated by Edwards III (1980: 53), that: "implementation orders may be accurately transmitted, clear and consistent, but if implementation orders lack the resources necessary to carry out policies, implementation is likely to be ineffective".

There are several things that need to be considered in the dimension of resources in implementing policies, namely; (1) adequate number of staff which should be adequate in terms of; (a) Quantity and capability in terms of their skills in carrying out policy instructions in the field through expertise and training; (b) Motivation; and (c) Information, which is included in two forms; Information about the procedures for implementing a policy by 
the implementers, namely how or what should and need to be carried out, funds and data about the compliance of the implementers of the instructions, compliance with the implemented regulations or laws or not. (2) Authority, the authority in implementing policies or programs will differ from one another, this depends on the job description, namely through: (a) Control method: persuasive and threat; and (b) Compliance with existing rules. (3) Facilities as a carrying capacity in the implementation of policies include the availability of buildings, equipment, and supplies.

Disposition, namely the occurrence of trends such as; (1) Impact of disposition, namely; (a) The homogeneity of administrators, and (b) The development of parochial views, namely the occurrence of seniorjunior relations and environmental influences. (2) Staff bureaucracy, namely the appointment of bureaucrats. (3) Manipulation of incentives.

Every policy implementation that is instructed by the employer through communicative and persuasive orders should result in the administrator behaving in a way that he accepts the implementation of the policy or program well. But if the opposite happens, implementation will experience difficulties and even failure in its implementation, as stated by Edwards III (1980: 89), as follows; "if implementers are well-disposed toward a particular policy, there are more likely to carry it out as the original decision-makers intended. But when the implementers' 'attitudes or perspectives differ from the decision-makers', the process of implementing a policy becomes infinitely more complicated".

Some policies are included in the zone of inattention by administrators. Which policies that lead to conflicts in the implementation with various views or objectives of the interests of the organization. This surely becomes the obstacle in the policy implementation as stated by Edwards III (1980:114), with the statement; "Some policies fall within the 'zone of indifferences' of administrator; other elicit strong feelings. These policies may conflict with implementers" substantive policy views or the personal or organizational interests. It is here that dispositions pose obstacles to implementation".

It is very possible for the disposition of the implementer to obstruct the implementation of the policy if the implementer does not agree with the substance of the policy that they must carry out. As some leaders of activities maintain or anticipate the balance of the policy to inspire their opposition. Sometimes implementation is hindered by complex situations, such as the implementers' affirming the implementation of a policy which they agree to divert to the achievement of other objectives as stated by Edwards III (1980: 115), below: "Disposition may hinder implementation when implementors simply disagree with substance of a policy and their disagreement leads them not to carry it out. In some instances top officials may refrain from establishing policies because they anticipate opposition..... Sometimes implementers delay in implementing a policy of which they anticipate opposition.... Sometimes implementation is impeded by more complex situations, such as when implementers delay in implementing a policy of which they may approve in the abstract in order to increase the chances of achieving another, competing policy goal".

\section{Bureaucratic Structure}

Bureaucracy has an important role in policy implementation even though it is a large and complex organization, a dominant organization that is capable of implementing every policy or program, and no organization as strong as a bureaucracy is able to survive in any situation no matter how much the external influences have affected it, even Edwards III emphasized that bureaucracy rarely dies. There are two characteristics in bureaucratic structure according to Edwards III's view (1980: 125-141), namely; (1) Standard Operating Procedures (SOP), which are related to; (a) Social problems and public affairs; (b) Dominant instructions at different stages; and (c) Different objectives lie in a broad and complex environment.

Basically, SOP is a bureaucratic work procedure arrangement in carrying out its functions and duties, in which the bureaucracy can manage its resources internally, both related to human resources, time, facilities and infrastructure. (1) Fragmentation, which is related to; (a) Surviving which is the power to survive; and (b) Not neutral choices in a policy.

Fragmentation is the ability of bureaucracy in dealing with external factors that can affect bureaucracy in the form of infrastructure (NGOs, political parties, and professional institutions) and superstructure (legislative, executive, and other state institutions).

\section{RESEARCH METHOD}

In this research, the author uses the interpretive paradigm with the action that is purposive in nature and the purpose is to understand the meaning of the research object. The type of research used in this research is the case study type with a qualitative descriptive method. The focuses on this research are; (1) Analysis of policy implementation on PKH in South Timor Tengah Regency, which is formulated in some research sub-focus namely; (a) Communication which is formulated again in some research sub-focus; (i) Information distribution method program (ii) The clarity on understanding the purpose of the program. (b) Resources which are also formulated into research sub-focus; (i) Level of Education; (ii) Supporting Facility; (iii) Budget. (c) Disposition 
of Tendencies for behavior and characteristic of policy implementing officer is also described into research subfocus; (i) Implementing Officer's Behavior; (i) Incentive. (d) Bureaucratic Structure is also formulated into research sub-focus; (i) SOP. (2) Inhibitory factors of policy implementation of PKH in South Timor Tengah Regency. This research was conducted in South Timor Tengah Regency, East Nusa Tenggara Province. Informants in qualitative research are determined intentionally (purposive sampling). This technique was chosen because the chosen informants had certain characteristics. Data collection techniques were done by interviewing, documenting and observing. Primary data and secondary data that have been collected were then processed through several stages namely; (1) Stages of Editing and (2) Stages of Interpretation. Data analysis was performed using data analysis from Miles and Huberman in Sugiyono (2014: 91), there are three techniques in qualitative data analysis, namely data reduction, data presentation, and conclusion.

\section{RESEARCH RESULTS AND DISCUSSION \\ Analysis of Policy Implementation of PKH in South Timor Tengah Regency.}

In general, the task of implementation is to link the realization of public policy objectives with the results of government activities. The implementation task includes the creation of a policy delivery system. It is designed uniquely and it is strived for achieving that specific goal. So public policy is a broad statement covering the goals, objectives and the realized method in the action program to achieve the goals set in the policy. To better assess a public policy implementation, it is necessary to know the variables and factors that influence it.

The implementation of the $\mathrm{PKH}$ program must be done transparently with an orientation that directs the implementation towards a better, more focused and consistent role of communication that supports the service so that it can be implemented well by following the goals of services. It aims to build communication between the central government, regional governments, program implementers and KPM to reduce the number of poverty. In this study, the researcher wants to see the Analysis of PKH Policy Implementation in South Timor Tengah Regency based on Edward III's theory, namely the dimensions of communication, resources, disposition and bureaucratic structure and the inhibiting factors of PKH Policy Implementation in South Timor Tengah Regency.

\section{Communication}

Communication has an important role in the execution of implementation and it will be effective if the measures and objectives of the policy are understood by the individuals responsible for achieving policy objectives. Thus, communication can be used to see whether the PKH program in TTS is effective or not. The implementation of the PKH program will be effective and successful if every person responsible for the program can carry out the program according to the rules, regulations and to whom the services are given.

Socialization is one of the keys to the success of a program, where the socialization that runs on the implementation of the PKH program in TTS District which not only focuses on aspects of implementation and successful implementation of the program but also on monitoring and developing policies, specifically in building support and commitment to institutionalize PKH in the form of Social Security system. The role of socialization through the PKH program will have an impact on the implementers of PKH, PKH KPM, relevant stakeholders and the general public where the purpose and objectives of the program as well as the mechanism for assisting have been effective. They are aimed to reduce poverty in the TTS District.

Communication in policy implementation includes several important factors. They are information transformation, clarity of information, and consistency of information. The transformation factor requires that information is not only conveyed to the policy implementer but also the target group and related parties. The clarity factor requires clear and easily understood information. This is also to avoid misinterpretation from the implementers of the policy, the target group or the parties involved in policy implementation. While the consistency factor requires that the information conveyed must be consistent so as not to cause confusion among policy implementers, target groups and related parties.

\section{Resources}

Edward III in Widodo (2011: 98) says that resources have an important role in policy implementation. The resources referred to here are related to all resources that can be used to support the successful implementation of policies. PKH facilitators are human resources recruited and appointed by the Ministry of Social Affairs as facilitators at the sub-district level. In general, the duties and responsibilities of sub-district facilitators are to carry out the task of assistance to beneficiary families.

In the implementation of PKH program policies in TTS, program implementers such as coordinators, assistants and PKH operators are human resources who play a role in helping the success of the implemented program. Through the role of PKH implementer, it will be more effective and efficient if the implemented program is accompanied directly. Thus, the community can be helped directly as program beneficiaries.

Based on the results of the interview, it is known that in the execution of the Family Hope Program, the role of human resources for the Head of Fields of Linjamsos, Koorkab, Koorcam, and Operators is to understand the 
roles they have to carry out starting from the undertaken recruitment activities, to the empowerment activities through facilities and used operational funds respectively. The role of the PKH HR in the assistance process must also have an impact on beneficiaries to ensure the development and circumstances of the target Family Hope Program. To determine whether it is going well or not perceived by the beneficiaries. Hence, the KPM as the beneficiary will be eligible to receive assistance.

The role of counterparts in this case the activities and frequencies carried out in accordance with regulations set by the ministry and activities carried out by the facilitators, in general, are group meeting activities aimed at providing education through activities in the use of access to services related to health, education and social welfare facilities. The role of the facilitators in the group is to keep observing the group's shortcomings. Thus, the facilitators should at the problems arising every month and they can change those problems to become the strengths that have an impact on the independence of KPM.

Non-human resources, namely infrastructure or facilities, are needed to translate the answers of the above PKH implementers in order to facilitate the implementation of services. Facilities are an indispensable factor in implementing a policy. Facilities can be in the form of offices, tools/equipment, and vehicles. Facilities and infrastructure are some of the factors that influence the implementation of policies. Based on the interviews with implementers of the Family Hope Program, they state that facilities are only adequate for implementers at the district level. Tools/equipment needed to support the performance of the facilitators should be provided still.

Human resources or implementers of the Family Hope Program in TTS can be said to have fully carried out their duties and responsibilities in accordance with technical guidelines and general guidelines in the implementation of the hope family program. However, the obstacles they have to face are particularly inadequate access to facilities and infrastructure and budget availability of 5\% in the form of sharing funds that have not been met.

\section{Disposition}

One of the factors affecting the policy implementation is the implementing officer's behavior. Disposition regarding the willingness of the implementers to carry out the public policy. Skills alone are inadequate, without the willingness and commitment to implement the policies. Behavioral tendencies or characteristics of the implementers of the policy play an important role to realize the implementation of policies in accordance with the goals or objectives. Important characteristics that must be possessed by policy implementers are honesty and high commitment. Honesty directs the implementers to remain within the expectations of the outlined program, while the high commitment of the implementers of the policy will make them to always be enthusiastic in carrying out the duties, authorities, functions, and responsibilities in accordance with the determined regulations from policy implementers will be very influential in the policy implementation.

This research aims to obtain from the disposition dimension of the attitude of the implementers and incentives in supporting the PKH program policies in the TTS District. Thus, the implementation in the field through the disposition dimension is in accordance with the provisions, namely in enforcing obligations in this case the component of the program implementer's role and the provision of services to beneficiaries in fulfilling each other's obligations properly.

Essentially, empowerment aims to help KPM get the power, strength, and ability to make decisions and actions to be taken and related to the KPM themselves, including reducing personal and social obstacles in taking action. People who have achieved collective goals are empowered through their independence; it even becomes a "necessity" to be more empowered through their own efforts and accumulation of knowledge, skills and other resources in order to achieve goals without depending on the help of the surrounding environment relations.

Empowerment in the program implementation is a process to change positive behaviors related to education, care, health, and economy and child protection. It is also the process to increase the ability of participants to recognize the potential within themselves and the environment so that it can be used in improving the family welfare. Related to the Family Program Hope, the empowerment is carried out through interventions of Family Capacity Building Meeting (P2K2) or Family Development Session (FDS) aimed at increasing the knowledge and awareness of KPM PKH about the importance of education and health in improving the quality of family life in the future. Thus, the fulfillment of obligations by KPM PKH is not only driven by fears of a reduction in the value of aid, but also because of the awareness of the educational and health benefits for the children of KPM PKH.

In general, verification and validation play a very important role in activities through agencies, sub-district coordinators and PKH facilitators, where the interview statement above illustrates the commitment of KPM PKH and updating data through activities providing health and education facilities. 


\section{Bureaucratic Structure}

The bureaucratic structure in the implementation of the Family of Hope Program provided by the Central Government from the highest level from the province to the lowest level such as the regions. The availability of these institutions is aimed at having its own duties and authorities in implementing PKH on each designated institution. The reason is that the clarity of duties and workload of each agency will provide convenience for other agencies in carrying out their duties. One of the important bureaucratic structure dimensions of each organization is to use the Standard Operating Procedure (SOP), where the implementation of the policy will run well if there is a Standard Operating Procedure (SOP) as a guideline for implementing policies that have been made to run systematically.

Based on the results of the study it can be seen that the distribution of PKH social assistance in TTS District provided to KPM is seen based on the determination of KPM PKH that already has a membership component (eligible) and has fulfilled obligations based on the PKH component criteria through group meetings or Family Ability Improvement Meetings (P2K2) monthly. Channels of assistance provided directly to KPM through the direct disbursement mechanism are already known by KPM through the accompanying role starting from opening an account at the bank to the method of withdrawal. Thus, this education can give an impact to KPM independently to utilize the assistance directly to meet the education, health and social welfare component needs.

The implementation of the Family of Hope Program in the TTS Regency has set the basic procedures for implementation, the basic procedures of work or standard operating procedures (SOP) are needed in the implementation of a policy. Basic work procedures are procedures or standards that are used as a reference in the implementation of a policy. The existence of basic work procedures can realize the implementation of the policy in accordance with the previously stipulated plan. This is consistent with the statement by George C. Edward III who says that by using standard operating procedures the implementers could make use of the available time and unify the actions of officials in the organization, in the bigger picture, the desired expectation is the realization of the Hope Family Program that could break the poverty chain.

Based on the informant's explanation, this can be done using standard operating procedures in the form of technical implementation of the program in which its standard operating procedures have already been understood and acknowledged. Thus, it can be concluded that the standard operating procedures in the implementation of the Family Hope Program in the TTS Regency are good enough based on the aspect of standard operational procedures. This means that actions in the organization are expected to be consistent with the complete standard operating procedures regarding the implementation of the Family Hope Program. Based on this, the implementation of the Family Hope Program in the TTS Regency is in accordance with the roles, tasks, and coordination between the implementing parties. The division of roles is intended to facilitate the implementation of this policy. Although each policy implementing apparatus has different duties, the coordination between the implementers and the government is needed to achieve the objectives of the Family Hope Program.

\section{Inhibiting Factors of PKH Policy Implementation in South Timor Tengah Regency}

The inhibiting factor in implementing a policy is a common process wherein each program has different problems in the field. Thus, the roles of various actors are provided to deal with problems arising in the implementation process. The Family of Hope Program (PKH) through the role of implementing actors up to the beneficiary families plays an active role. It has been trusted in implementing the program without neglecting the problems related to program implementation.

The results of research conducted through interviews with implementers and beneficiaries can provide an illustration of the extent to which there are inhibiting factors that occur in the implementation of the program. Hence, inhibiting factors in the implementation of the Family Hope Program (PKH) in the TTS District can be described as following.

One of the inhibiting factors in the implementation of the Family Hope Program (PKH) in TTS District is the weaknesses of KPM which can be seen from empowerment activities to change behavior and attitudes. For example, there is still KPM who still does not understand the role of PKH as a program in supporting KPM household income. However, there are KPM who have succeeded in increasing family income and no longer have a role as KPM. That is why implementers still have a role by working hard in changing behavior and attitudes so as not to always depend on the program and escape poverty.

The results of interviews show that there are still many KPM who lack awareness in fulfilling identity data. This makes it difficult for the facilitator to control and monitor. However, assistance is provided in assisting in composing KPM identity data through the role of the facilitator. For funds disbursement, it is still necessary to have direct communication with the village by banks related to the disbursement of funds. It will make it easier for KPM to withdraw funds. Human resources also need to be considered to ensure that the addition of human resources can spread throughout regions where generally poor community lives. 
The results of the interview above show that the obstacle perceived by the operator is the unavailability of media. Due to this obstacle, the facilitator is only able to provide assistance through discussion and everything related to technology is still hampered by the cellular telephone network in the assisted area. It puts the facilitator in a difficult situation when they want to send data for data entry such as in the case of verification and validation to the operator.

\section{CONCLUSION}

Based on the research objectives and the results of the discussion, some conclusions have been drawn as follows:

1. The implementation of the Family of Hope Program (PKH) in South Timor Tengah Regency can be concluded as well-executed after observing the role of the implementers and the beneficiary families of the program. Policy implementations of PKH in South Timor Tengah Regency according to Edward III theory are: (1) Communication Dimension, Transmission or information distribution on the Hope Family Program given by the implementing officer has been understood well by the KPM. (2) Resources Dimension, Assistant has done a good mentorship process. However, facilities and infrastructure, regional topography in the implementation of $\mathrm{PKH}$ are not adequate in the mentorship process. (3) Disposition Dimension, Implementing an officer's behavior describes the commitment, the attitude of the beneficiary community of PKH who have done the obligation well. (4) Bureaucratic Structure Dimension, There is a standard operating procedure (SOP) for the implementation, so the coordination between social service, the government, and the assistant has been done perfectly.

2. There are two obstacles in the implementation of the Family Hope Program (PKH) in South Timor Tengah Regency. First, the difficulty in accompanying the socialization of the PKH program because of the low KPM resources that have not been maximally accepted in the program. Second, the topographic problems that become the difficulties in providing assistance such as road and distance access problems, communication access, in this case, telephone network problems that hamper sending data to PKH operators. The reason is that they must directly use the "door to door" method to the homes of each $\mathrm{PKH}$ recipient to ensure the implementation of $\mathrm{PKH}$.

\section{SUGGESTION}

Based on the conclusions obtained from the results of the research above, the researcher gives some suggestions that could be used as input and consideration to properly carry out the implementation of the Family Hope Program in TTS. The suggestions are:

1. Maintaining the implementation of the Family Hope Program socialization on an ongoing basis to ensure that the community can fully understand the implemented program.

2. There needs to be supervision, monitoring, and evaluation from the Social Service on the implementation of the Family Hope Program in South Timor Tengah Regency.

3. The awareness of the South Timor Tengah Regency Government in the form of a 5\% sharing fund is in accordance with the provisions. It can be seen as a form of poverty alleviation commitment.

4. The awareness of the South Timor Tengah Regency Government through the Social Service to prepare supporting facilities and infrastructure as well as other supporting facilities to improve the efficiency and effectiveness of the program.

5. PKH HR is always committed to upholding the obligation to accompany beneficiary families to change behavior and improve the economy through empowerment activities.

6. Maximizing cross-sectoral coordination as an effort to reduce poverty has become a stigma for South Timor Tengah Regency.

\section{REFERENCES}

Arikunto, Suharsimi. 2013. Prosedur Penelitian Suatu Pendekatan Praktik. Yogyakarta : Rineka Cipta. Ahmadi, Rulam. 2014. Metodologi Penelitian Kualitatif. Yogyakarta : Ar-Ruzz Media.

Bessant, Judith, Robb Watss, Tony Dalton dan Paul Smith. 2006.Talking Policy How Social Policy In Made. Crows Nest : Allen and Unwin.

Bungin, Burhan. 2011. Penelitian Kualitatif. Jakarta : Kencana Media Group.

Dunn, William N. 2003. Pengantar Analisis Kebijakan Public Edisi Kedua. Yogyakarta : UGM.

Edward III, George C. 1980. Implementing Public Policy. Wasington D.C. : Congressional Quarterly Inc. 
Khomsan, Ali, dkk. 2015. Indikator Kemiskinan dan Misklasifikasi Orang Miskin. Jakarta : Yayasan Pustaka Obor Indonesia.

Liliweri, Alo. 2018. Paradigma Penelitian Ilmu-ilmu Sosial: Menelusuri Jejak Positivisme - Interpretive - Konstruktivisme Critical Theory - Posmodern - Feminisme dan Pragmatisme. Kupang : Universitas Nusa Cendana.

Moleong, Lexy J. 2014. Metodologi Penelitian Kualitatif. Bandung : PT. Remaja Rosdakarya.

Nazir, M. 2014. Metode Penelitian. Jakarta : Ghalia Indonesia,.

Nugroho, Riant. 2017. Public Policy. Jakarta : PT. Elex Media Komputindo.

Purwanto, Agus, Erwan dan Dyah Ratih Sulirtyastuti. 2012. Implementasi Kebijakan Publik: Konsep dan Aplikasinya di Indonesia. Yogyakarta : Gava Media.

Sukmadinata, Nana S. 2010. Metode Penelitian Pendidikan. Cetakan ke-4. Bandung :PT. Remaja Rosdakarya.

Sulistiyani, Ambar Teguh. 2004. Kemitraan dan Model Model Pemberdayaan. Yogyakarta : Gava Media.

Sugiyono. 2014. MemahamiPenelitian Kualitatif. Bandung : CV. Alfabeta

2016. Metode Penelitian Kuantitatif, Kualitatif, dan R\&D.Cetakan ke-23. Bandung: CV. Alfabeta.

Suharto, Edi. 2010. Membangun Masyarakat Memberdayakan Rakyat. Bandung : PT. Refika Aditama.

2015. Analisis Kebijakan Publik : Panduan Praktis Mengkaji Masalah dan Kebijakan Sosial. Bandung : CV. Alfabeta.

Tim Penyusun Kamus. 1991. Kamus Besar Bahasa Indonesia. Jakarta : Balai Pustaka.

Winarno, Budi. 2016. Kebijakan Publik Era Globalisasi. Yogyakarta: Center of Academic Publising Service (CAPS).

Widodo, Joko. 2001. Good Governance; Telaah dari Dimensi Akuntabilitas dan Kontrol Birokrasi pada Era Desentralisasi dan Otonomi Daerah. Surabaya : Insan Cendikia.

Wrihatnolo, Randy R, dkk. 2002. Manajemen Pemberdayaan, Sebuah Pengantar dan Panduan untuk Pemberdayaan Masyarakat. Jakarta : PT. Elex Media Komputindo.

Jurnal dan Dokumen

Nainggolan, Togiaratua dan Badrun Susantyo. 2017. Upaya Percepatan Penanggulangan Kemiskinan Melalui Pogram Keluarga Harapan Studi di Empat Daerah di Indonesia. Jurnal Sosio Konsepsia Vol. 7, No. 01, September Desember, Tahun 2017

Nainggolan, T. dkk. 2012. Program Keluarga Harapan di Indonesia: Dampak Pada RTSM di Tujuh Provinsi. Jakarta : P3KS Press

Fitria, Dewi. 2016. Efektivitas Program Keluarga Harapan (PKH) pada Dua Wilayah Pilot Project PKH Jakarta Utara dan Kabupaten Sikka

Riyadi, Slamet. 2016. Analisis Implementasi Program Keluarga Harapan Terhadap Keluarga Sangat Miskin (KSM) Penerima Bantuan (Studi di Kecamatan Gunung Sugih Kabupaten Lampung Tengah). Program Studi Magister Ilmu Pemerintahan Fakultas Ilmu Sosial dan Ilmu Politik Universitas Lampung Bandar Lampung. 2016.

Suharto, Edi dan Djuni Thamrin. 2012. Program Keluarga Harapan (PKH): Memotong Mata Rantai Kemiskinan Anak Bangsa. Jurnal Aspirasi Vol. 3No. 1, Juni 2012

Godoy, Leticia María Delgado. 2015. The Impact of Municipal Socio-Economic Characteristics on the Implementation of Conditional Cash Transfers (Ccts): a Study of the Bolsa Família Program in Brazil. Universidad Complutense De Madrid

Kementrian Sosial RI, Pedoman Pelaksanaan PKH Tahun 2017 Direktorat Jaminan Sosial Keluarga, Dirjen Perlindungan dan Jaminan Sosial Kementrian Sosial Republik Indonesia, Edisi Tahun 2017. Jakarta

Kementrian Sosial RI, Petunjuk Teknis PKH “Penyaluran Dana Bantuan Sosial Non Tunai' Tahun 2018, Direktorat Jaminan Sosial Keluarga, Dirjen Perlindungan dan Jaminan Sosial Kementrian Sosial Republik Indonesia, Edisi Tahun 2018. Jakarta

Sekretariat Wakil Presiden Republik Indonesia. 2010. Penanggulangan Kemiskinan: Situasi Terkini, Target Pemerintah, dan Program Percepatan. Edisi II Tim Nasional Percepatan Penanggulangan Kemiskinan. Jakarta.

Suharto, Edi. 2006. Kebijakan Sosial. Disampaikan pada Diklat Jabatan Fungsional Pekerja Sosial Tingkat Ahli, Jenjang Madya, BBPPKS. Lembang 14 November 2006. Bandung.

Peraturan

Peraturan Presiden Republik Indonesia Nomor 15 Tahun 2010 Tentang Percepatan Penanggulangan Kemiskinan.

Kementrian Sosial RI, Pedoman Pelaksanaan PKH Tahun 2017 Direktorat Jaminan Sosial Keluarga, Dirjen Perlindungan dan Jaminan Sosial Kementrian Sosial Republik Indonesia. Edisi Tahun 2017.

Keputusan Menteri Koordinator Bidang Kesejahteraan Sosial Nomor : 31/KEP/MENKO/-KESRA/IX/2007, tentang Tim Pengendalian Program Keluarga Harapan, tanggal 21 September 2007

Peraturan Presiden Republik Indonesia Nomor 2 Tahun 2015 Tentang Rencana Pembangunan Jangka Menengah Nasional (RPJMN) 2015-2019. Kementerian Perencanaan Pembangunan Nasional/Badan Perencanaan Pembangunan Nasional 2014. 